\title{
A FUTURE OF CAPITALISM
}


This page intentionally left blank 


\title{
A Future of Capitalism
}

\section{The Economic Vision of Robert Heilbroner}

\author{
Michael C. Carroll
}

Assistant Professor of Economics

Muskingum College

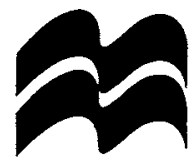


Houndmills, Basingstoke, Hampshire RG21 6XS and London

Companies and representatives throughout the world

A catalogue record for this book is available from the British Library.

ISBN 978-1-349-39910-9 ISBN 978-0-230-37251-1 (eBook)

DOI $10.1057 / 9780230372511$

First published in the United States of America 1998 by

ST. MARTIN'S PRESS, INC.,

Scholarly and Reference Division,

175 Fifth A venue, New York, N.Y. 10010

ISBN 978-0-312-17754-6

Library of Congress Cataloging-in-Publication Data

Carroll, Michael C., 1958-

A future of capitalism : the economic vision of Robert $\mathrm{L}$.

Heilbroner / by Michael C. Carroll.

p. $\mathrm{cm}$.

Includes bibliographical references and index.

ISBN 978-0-312-17754-6 (cloth)

1. Heilbroner, Robert L. 2. Economists-United States.

3. Economics-United States. 4. Capitalism. I. Title.

HB119.H44C37 1997

$330.12^{\prime 2}-\mathrm{dc} 21$

(c) Michael C. Carroll 1998

Softcover reprint of the hardcover 1st edition 1998 978-0-333-67363-8

All rights reserved. No reproduction, copy or transmission of this publication may be made without written permission.

No paragraph of this publication may be reproduced, copied or transmitted save with written permission or in accordance with the provisions of the Copyright, Designs and Patents Act 1988, or under the terms of any licence permitting limited copying issued by the Copyright Licensing Agency, 90 Tottenham Court Road, London W1P 9HE.

Any person who does any unauthorised act in relation to this publication may be liable to criminal prosecution and civil claims for damages.

The author has asserted his right to be identified as the author of this work in accordance with the Copyright, Designs and Patents Act 1988.

This book is printed on paper suitable for recycling and made from fully managed and sustained forest sources.

$\begin{array}{llllllllll}10 & 9 & 8 & 7 & 6 & 5 & 4 & 3 & 2 & 1\end{array}$

$\begin{array}{llllllllll}07 & 06 & 05 & 04 & 03 & 02 & 01 & 00 & 99 & 98\end{array}$ 
For my wife

Cyndi 
This page intentionally left blank 


\section{Contents}

$\begin{array}{ll}\text { Preface } & \text { ix }\end{array}$

1 Introduction 1

2 The Man and His Vision 5

3 Limitations of Traditional Economics 21

4 The Methodology of Worldly Philosophy 37

5 The Structure of Capitalism 59

6 A View to the Future 79

7 A Final Appraisal 91

$\begin{array}{ll}\text { Notes } & 99\end{array}$

The Economic Writings of Robert Heilbroner 101

Bibliography 111

$\begin{array}{ll}\text { Index } & 115\end{array}$ 
This page intentionally left blank 


\section{Preface}

Since I began this study almost two years ago, I have had the pleasure of speaking to a large number of fellow economists from around the ylobe about the substance of Heilbroner's work. At every conference Ind academic meeting it is interesting to note that the first comment I eceive is always some expression of admiration of Heilbroner's writing ityle; how much each had 'enjoyed' his books. Rarely do they begin by 1greeing or disagreeing with the content of his economics.

I hope in some small way this volume can contribute to an appreciaion of Heilbroner's work as a whole. There is a serious message in his zarefully crafted words. His thirty-plus books and hundreds of articles Jffer a social analysis unlike that of any modern economist. His ipproach is holistic, sociopolitical and always penetrating. It clearly leserves to be understood.

While I cannot thank all who have helped me with this work, I must, however, single out the efforts of my brother Mark R. Carroll for his zareful reading of the many revisions of this manuscript. His help and nspiration have led to so many improvements of this volume. Any misconceptions or overt mistakes in this work are of course my own and not his.

I would like to acknowledge the efforts of Terrel Gallaway and N. Shilling. They willingly listened to all my rambling and always returned a thoughtful reply. Also, Alice Sherrill, Leota Wolf, Ava Darr, Gerri Ford, and Duane Pool have all contributed in their own way.

I would also like to thank Robert Heilbroner for his inspiration and assistance early in this project. His generosity and openness have made this project possible. Further, I must thank my wife Cyndi for her patience and understanding. I could never have finished without her help.

Finally, I am especially grateful for the generous advice and guidance of J. Ron Stanfield. He has forever opened my eyes to the true world of economics. This, of course, is a debt I can never repay.

Portions of this book are taken from a dissertation submitted to the Academic Faculty of Colorado State University in partial fulfilment of the requirements for a degree of Ph.D. 